\title{
The Hermetica as Ancient Science
}

\section{Robert Zoller}

The Corpus Hermeticum ${ }^{1}(\mathrm{CH})$ is a compilation of philosophical, theosophical, mystical and cosmological texts dating, in their present form, from the third-fourth centuries C.E. and attributed, according to tradition, to Hermes Trismegistus. These texts exerted considerable influence upon western philosophers, scientific thinkers and mystics throughout the Middle Ages, especially influencing the Renaissance Neoplatonists. Scholarly discussions of the Hermetica once focused upon this Corpus, which some have felt contains lofty ideals and noble speculations.

Recently, however, attention has been turning to that other source of Hermetica which is neither a Corpus nor so lofty, namely the numerous texts, scattered in sundry libraries around the world, which deal with the practical aspects of the occult arts of astrology, alchemy and magic alluded to in the philosophical corpus. This literature has not yet been collected, edited and translated and hence cannot itself yet be considered a 'corpus'. In many cases there is dispute as to precisely which texts can even claim legitimately to be a part of the relevant literature. ${ }^{2}$ Occasionally there is no clear idea of the true author, while the dating of many of these texts is in doubt. In addition, there are few critical editions and until recently there has been a reluctance on the part of scholars to take this literature seriously.

The reluctance to study this material may be due to the fact that its subject matter varies so dramatically from that of the Corpus Hermeticum $(\mathrm{CH})$, which contains religio-philosophical opinions and may be tagged 'the philosophical hermetica'. The other astrological, alchemical and magical literature dealing with practical matters, on the other hand, may be termed 'the practical hermetica'. It has been asserted, principally by Walter Scott, that these literatures share only the appellation 'hermetic', and otherwise cannot be considered connected in any way. That is, the cosmological teachings of the philosophical hermetica have been divorced by modern scholars from the astrological teachings of the practical hermetica. However, other points of view are now emerging, and more recently Garth Fowden has argued that, contrary to Scott's opinion, the philosophical hermetica and the practical hermetica were conceived of as a

Robert Zoller, 'The Hermetica as Ancient Science', Culture and Cosmos, Vol. 1 no 2, Autumn/Winter 1997, pp.23-34. 
unity: the former providing the theory, the latter the practice, of a religiophilosophical world view the roots of which extend back to ancient Egypt. ${ }^{4}$

The issue of ultimate origins, derivations, dates and authorship aside, there is internal evidence from the texts that both the philosophical and practical hermetica might, as Fowden claims, be legitimately viewed as a unity. If we regard the practical hermetica together with the philosophical hermetica as comprising the theory and practice of a peculiar world view, we may see the combination of the two as evidence of a Hellenistic effort to produce a religious science (or scientific religion).

Study of the texts in this way uncovers the presence of several principles (Principia Hermetica) in both the philosophical corpus and in many of the various practical hermetic texts, suggesting that the authors of these texts were expressing the same religio-philosophical dogmas found in the $\mathrm{CH}$ while applying them as a kind of scientific method in the practical texts.

I say 'as a kind of scientific method' because the Hermetica do not comprise a science in the contemporary sense. There is no attempt to arrive at an hypothesis on the basis of repeated observations and duplicatable demonstrations under controlled conditions. The hermetic principles are initially arrived at through mysterious and, we would say, uncertain, means. For instance, the first text in the Corpus, the Poimandres, depicts the author as achieving cosmological, theosophical, spiritual and 'scientific" knowledge simultaneously via a meditation-like experience. The transmission of such 'scientific' principles is through instruction by a preceptor to a disciple or philosophical 'son'. Thus, while the hermetica do not present us with a science in the modern western sense, they can be considered a 'science' in the pre-modern sense, in a manner very like that signified in Medieval Islam by the words 'ilm (science) and hikma (wisdom). We may even see the hermetica as comprising a scientia in the sense of that word prior to the specialist usage it received after the 16th century, i.e. as the consistent and systematic practical application in the arts of wise insights into the nature of things.

In this paper I will identify the major principles of the philosophical hermetica and argue that they underpinned the teachings found in contemporaneous astrological and magical texts, and that the latter are therefore central to an understanding of the former, and themselves possess a philosophical coherence which has often been ignored. I do not propose to outline the practical applications of the hermetica in detail. My purpose here is to provide a basis for future work. 


\section{The Philosophical Hermetica}

We may identify at least five Principia Hermetica in the philosophical Hermetica $(\mathrm{CH})$. They are:

1. Eternity of the Soul

2. Circulation

3. Apokatastasis

4. Heimarmene/Ananke

5. Unio oppositionum

In what follows, we will look at each of these in order, giving citations from the $\mathrm{CH}$.

1. The Soul, according to the $\mathrm{CH}$, is immortal. Created by 'Mind, the Father of All' in his own image, Man 'is immortal by reason of the Man of eternal substance' ${ }^{6}$

2. Circulation is the process by which the soul descends into Matter through the spheres and re-ascends to heaven (the Ogdoad). ${ }^{7}$ In the Poimandres 14 and 24-26, we learn of the descent and ascent of the human soul as it incarnates at birth and re-ascends to heaven following death. Transmigration, a form of circulation, is found in Excerpt XXVI Isis to Horus, ${ }^{8}$ where we learn that the souls that have been released from bodies and those which have not yet been embodied, haunt the region between earth and heaven. From this region these souls are led 'from time to time' to embodiment. Some souls enter human bodies, some the bodies of animals.

3. Apokatastasis (Restoration) was a very important concept to the Greeks, especially to the Stoics and Neoplatonists. According to this concept, the world would be renewed when the celestial bodies returned to their original positions, an event which would be reflected in a terrestrial purging by means of conflagration and inundation. The belief in periodic cosmic renewal was supported by Plato in the Timaeus, was taken as almost a sacrament by the Stoic philosophers and was eventually adopted by the Neoplatonists, especially Proclus, ${ }^{9}$ as well as by the Hermetic philosophers. ${ }^{10}$ We find this concept referred to in the Corpus in the Latin 
Asclepius (26a) ${ }^{11}$ where, after prophesying that there will come a time when Egypt will be desolate and irreligion will be the rule, the text has:

'But when all this has befallen, Asclepius, then the Master and Father, God, the first before all, the maker of that god who first came into being, ${ }^{12}$ will look on that which has come to pass, and will stay the disorder by the counterworking of his will, which is the good. He will call back to the right path those who have gone astray; he will cleanse the world from evil, now washing it away with waterfloods, now burning it out with fiercest fire, or again expelling it by war and pestilence. And thus he will bring back his world to its former aspect, so that the Kosmos will once again be deemed worthy of worship and wondering reverence, and God, the maker and restorer of the mighty fabric, will be adored by the men of that day with unceasing hymns of praise and blessing. Such is the new birth of the Kosmos; it is a making again of all things good, a holy and awe inspiring restoration ${ }^{13}$ of all nature; and it is wrought in the process of time by the eternal will of God.'

Elsewhere we read: 'Living creatures do not die, my son; but they are composite bodies, and as such, they undergo dissolution. Dissolution is not death; it is only the separation of things which were combined; and they undergo dissolution, not to perish, but to be made anew. ${ }^{14}$

4. Heimarmene is Destiny ${ }^{15}$ which works through measure, ${ }^{16}$ periods, ${ }^{17}$ and time,$^{18}$ that is, through the movement of the stars and planets, while Ananke is Necessity, ${ }^{19}$ the effect of Heimarmene. Heimarmene and Ananke are presented here as a unit from the observation that they never occur separately, Heimarmene being the root of Ananke. In the $\mathrm{CH}$ we run into the idea of Heimarmene frequently. In Libellus $I$. it is said to be the cause of births, while elsewhere we are told that no one escapes Destiny. ${ }^{20}$

5. Unio oppositionum (The Union of Opposites) is not expressed overtly in the $\mathrm{CH}$ but underlies much of its doctrine. For instance, the polarization of Celestial Man, ${ }^{21}$ created by Mind the Father, and Nature (the Material Cause $)^{22}$ are united in Poimandres 14, 15. The 'man' so produced is twofold (consisting of body and mind), physical, bisexual and participates in the characteristics of the seven planet-administrators. A polarization, which is presented as being ultimately unified, is the relation of terrestrial man to the eighth sphere or heaven (the goal of the ascended soul). 


\section{The Practical Hermetica}

These principia hermetica, presented in the philosophical corpus as religious or mystical concepts, are also found in the practical hermetica as ancient scientific methods or principles. In alchemy the operator (frequently referred to as the 'Artist' in alchemical texts) circulates, dissolves, calcines, sublimes and precipitates substances, often for a fixed number of repetitions or for a determined period of time, in order to arrive at their indestructible essence.

In astrology, the practitioner observes the positions of planets and stars in their periodic revolutions at specific times and places in order to prognosticate the future destiny. He notes also the positions opposite to such positions recognizing the importance of polarity in his work. This polarity is reflected in the very graphic arrangement of the charting he does in order to record the figure of the heavens at any given moment. His work is a study of times, measure and periods and he frequently avails himself of revolutional figures (horoscopes set for important moments in the annual cycle, such as ingresses) in his delineations, even while he contemplates that which does not change.

The magician, who attempts to redirect the course of destiny, dramatizes his unchanging will with movements and behaviour which recapitulate the celestial motions. He circumambulates a given number of times, singing or chanting, and observes the astrologically auspicious times for performing his rituals, conforming them to the periods of the planets and stars. He endeavours to attain the conscious blending with the divine Unity, the unchanging or Eternal Self, from which all magical transformations are possible. He observes opposites, often seeking one thing through the manipulation of its opposite. He repeatedly performs his rituals a set number of times.

Thus in alchemy, ${ }^{23}$ the principle of 'Eternity of the Soul' is seen in the purum $^{24}$ which remains after the apokatastasis of repeated purification via fire (calcination) and water (solution) via Circulation (distillation and precipitation). Heimarmene is manifest through the measure, i.e. in the length of time in which the operation is completed (e.g. 40 days). The unio oppositionum is embodied in the final conjunction, in the primigenious heat and the radicale humidum. In astrology, ${ }^{25}$ Eternity of the Soul ${ }^{26}$ and Circulation $^{27}$ appear with the presentation of the stars as stations for the ascent and descent of the soul. Apokatastasis is manifested in the 
astrological doctrine of revolutions or celestial figures for the moment the Sun returns to the position it held at birth (Anniversaries or Solar Returns) and in the general observation of the periodic returns of planetary and stellar bodies to a starting point of some sort. ${ }^{28}$ Heimarmene/Ananke is found in Firmicus' 4th century CE astrological treatise, the Mathesis in the words '...God, the Creator of the Universe, who has made and regulated everything under the control of everlasting Necessity.... ${ }^{29}$ Unio oppositionum occurs in Firmicus in that the Sun and Moon each rules one sign while the five planets have two houses each, one masculine, the other of the opposite gender, i.e. feminine. The astrologer stated 'how fitting it is that while the Sun is ruler of a masculine sign the Moon rules a feminine one, so that each claims a sign which is suited to its own sex. The other five planets have, as we have said above, two signs in which they exercise their authority. But of the signs which each possesses one is masculine, the other feminine. ${ }^{30}$ Thus, the twelve signs of the zodiac are divided into two complementary but opposing parts, six masculine and six feminine. ${ }^{31}$ In ancient magic, especially in its mode as theurgia (the acquisition of godlike powers by men via ceremonial 'initiations'), we find an eight-fold initiation implicit in the Poimandres and in Iamblichus' On the Mysteries of the Egyptians, Chaldeans and_Assyrians, ${ }^{32}$ which seems to have consisted of eight degrees, corresponding to the seven visible planets plus the 8th sphere. It also appears to have been influenced by Plato ${ }^{33}$ who portrayed the Demiurge as creating souls in equal number to the stars and sowing them in the fixed stars of heaven; later they descend to the 'organs of time', i.e. the planets; and finally to earth where they are embodied. The Hermetic initiation reverses this descensus and entails an ascent through the spheres to the Ogdoad or sphere of the fixed stars. Central to this ascensus is the discovery of the Lord of the Geniture (the birth horoscope), for by means of this knowledge freedom from fate is achieved. As Iamblichus tells us in On the Mysteries, this could be discovered either by artificial means [i.e. by astrology], or by divination [i.e. by theurgia]. Once this ascensus has been achieved, the initiate is heir to both the knowledge of the gods and to god-like power. Having become a Son of God, ${ }^{34}$ he now has magical abilities. This ascensus animae was to be dubbed in the Renaissance occultism of Henry Cornelius Agrippa, the 'dignificatio'. 35

The actual theurgic operation or liturgy involved the following elements which related to the philosophical hermetica: fasting and purification (including ritual bathing and ablutions) [Apokatastasis]; exploitation of the knowledge that the highest part of the mind, the nous, was already united to 
the gods [Eternity of the Soul]; the use of song and dance often in connection with geometrical designs or forms, e.g. letters or characters [representing Heimarmene/Ananke]. ${ }^{36}$ The union of the human soul to the divine mind [Unio oppositionum]; circumambulation [Circulation].

\section{Conclusion}

It can be seen therefore that the same conceptual principles are to be found in both the philosophical hermetica and the practical hermetic texts treating of astrology, alchemy and magic/theurgy. In the philosophical hermetica these principles are presented morally, mystically, religiously or as cosmology. In the practical hermetica they provide concrete features of the art in question which contribute to the successful realization of the goals the art seeks.

What the historian of religion gains by this point of view is the recognition that alchemy, astrology and magic were far more than aberrations of the ancient mind. They constituted an ancient science, widely accepted by the contemporary intelligentsia, and as such they provided ancient religious thinkers with a justification for religious themes as well as a structure on which to construct the scientific means by which religious dogma might be supported. It is also possible that the principles of hermetic astrology and alchemy contributed to the conceptualising of religious doctrines and that without an understanding of these disciplines in their own contexts, on their own terms, we may not fully understand the subtleties of various classical religious traditions. Finally, as a result of the modern idea of the incompatibility of science and religion, we are inclined too frequently, I believe, to treat religious doctrines, both ancient and modern, as completely unrelated to their contemporary scientific atmosphere. Yet the influence of modern science on modern religion has been pervasive and important. This paper suggests that the influence of ancient science was at least equally influential upon ancient religious ideas.

\section{References}

1. I have used Walter Scott's Hermetica, published in 4 volumes with commentaries by Dawsons of Pall Mall, London, 1968. The most recent edition was published by Hermes House, Boulder, 1982. All references are to Volume 1.

2. In the analysis and comment on the practical hermetic texts below I am taking as 'hermetic' texts such as are attributed to Hermes, cite Hermes as a source or are reputed to contain 'hermetic' material. Of astrological texts I rely upon Firmicus 
30 The Hermetica as Ancient Science

Maternus' Mathesis and the Liber Hermetis Trismegisti. Of alchemical texts the Revelations of Morienus, ancient adept and hermit of Jerusalem to Khalid ibn Yazid ibn Mu'awiyya, king of the Arabs of the divine secrets of the magisterium and accomplishment of the alchemical art. Of magical (theurgical) texts, I take Iamblichus' On the Mysteries as an example of Hermetic-Neoplatonic theurgical theory and Picatrix as a practical magical text. The last is a medieval text, written about 1000 C.E. but containing material which goes back to at least the 4th century. I have used David Pingree's edition of Picatrix Latinus, published by the Warburg Institute, London. Frances Yates says that the Picatrix is 'probably 12th century' (Giordano Bruno and the Hermetic Tradition, Chicago, 1964, p 49). David Pingree writes in Il Neoplatonismo nel Rinascimento, Pietro Pini, Instituto della Enciclopedia Italiana, 1993, p.135, that the author of the Picatrix (Ghayat al hakim) 'was laboring in Spain in the twelfth century...' nevertheless assures us that this author was relying on material derived from Harran. He refers to the Harranian Sabians who first appear in the 9th century when the calif Al-Mamun stopped at Harran on his way to fight rebels in Persia to investigate the orthodoxy of the Harranians. He found them to be practicing astral polytheists practicing astrological magic such as is found in the Picatrix. The connection between Harran and the Picatrix is unquestioned.

3. Scott, Hermetica, vol. I, p.1: 'We are therefore justified in treating the 'religious' or 'philosophic' Hermetica as a class apart, and, for our present purpose, ignoring the masses of rubbish which fall under the other head'.

4. Garth Fowden, The Egyptian Hermes: A Historical Approach to the Late Pagan Mind, Princeton University Press, 1986.

5. See Poimandres (Libellus I) paragraphs 4 and 5, which describe the initial part of the mystic's vision and contain a description of the creation of the primeval 'watery substance' from the 'mild and joyous light'. While this passage is susceptible of many interpretations and is remarkably similar to the account of the beginning of things found in Philo Byblius' forged Sanchoniathon (allegedly the Phoenician Cosmogony and Theology), it is also suggestive of an alchemical interpretation as a description of the genesis of the materia prima. I have used Scott's Hermetica, London, Dawson's of Pall Mall, 1968. The Poimandres begins on page 2. I have compared Scott's English translation with Copenhaver's (Hermetica trs by Brian Copenhaver, Cambridge, 1992).

6. Scott, Hermetica, Libellus I, 12 \& 15, p 120,1.

7. In the words of the Emerald Tablet: 'With great sagacity it ascends from Earth to Heaven. Again it descends to Earth, and unites in itself the force from things

Culture and Cosmos 
superior and things inferior.' E.J.Holmyard, Alchemy, Penguin Books, 1957, (Dover, NY, 1990, pp 97).

\section{Scott, Hermetica, page 515.}

9. Plato, Timaeus, 39 D. See also Proclus, Elements of Theology, trs. Dodds, Oxford, 1933, p. 174

10. It is also a feature of the Judeo-Christian tradition, witness Genesis 6-9: the story of Noah's Flood in which God purifies the corrupt antediluvian world by a Flood.

11. Scott, Hermetica, pp 345-347.

12. The Kosmos is the god who first came into being.

\section{Apokatastasis}

14. Libellus XII (ii).16 Scott, Hermetica, p 233. Also cf. Excerpt IIA Hermes to Tat, 16 (Scott, p 387): 'And all things on earth are overtaken by destruction; for without destruction things cannot come into being. The things which come into being must needs arise out of those which are destroyed; and the things which come into being must needs be destroyed, in order that coming-into-being may not stop.'

\section{Libellus 1.15, Scott, Hermetica, p 122-3.}

16. Measure as a concept permits numbering of periods and time. A thing's fate or Destiny is related to its form. All form is measured. Throughout the Corpus Hermeticum references are made to the measure of Man and Kosmos as well as, by way of contrast, to God's immeasurability (and hence His being above or beyond Fate or Destiny). Cf, e.g. Asclepius I, (Scott, Hermetica, p. 301) where God, 'fashioned man of the substance of mind and the substance of body, --of that which is eternal and that which is mortal, --blending and mingling together portions of either substance in adequate measure...' The measure of the Kosmos may be known through music Cf, e. g. Asclepius I, (Scott, Hermetica, p. 311), 'And to know the science of music is nothing else than this, --to know how all things are ordered, and how God's design [ ratio = logos] has assigned each its place; for the ordered system in which each and all by the supreme Artist's skill are wrought together into a single whole yields a divinely musical harmony, sweet and true beyond all melodious sounds.' God is without limits, cf, e.g. Libellus VIII, (Scott, Hermetica, p. 311): 'God...has in himself the only limit of his own pre-eminence.' Also cf. Libellus I: 'If you do not make yourself equal to God, you cannot apprehend God; for like is known by like. Leap clear of all that is corporeal, and make yourself grow 
to a like expanse with that greatness which is beyond all measure; rise above all time, and become eternal; then you will apprehend God.' (Scott, Hermetica, p. 221).

17. The periodic movements of the stars and planets are the physical manifestation of the abstract idea of periodicity. 'For the movement of the Kosmos varies the births of things, and gives them this or that quality,...' Scott, Hermetica, p.183. (sec 7, of Libellus I).

18. 'A Discourse of Mind to Hermes', Scott, Hermetica, vol. I, p. 207: 'God, Aeon, Kosmos, Time, Coming-to-be./ God makes the Aeon,/ The Aeon makes the Kosmos,/ The Kosmos makes Time,/ and Time makes Coming-to-be.' Also, Cf. Asclepius III, sec 30, Scott, Hermetica: 'The process of time is wholly determined by God's law; but the lapse of terrestrial time is marked by the changing states of the atmosphere, and the variations of heat and cold; while that of celestial time is marked by the return of the heavenly bodies to their former positions [apokastasis] as they move in their periodic revolutions. The Kosmos is that in which time is contained...'.

19. Scott, Hermetica, p232 \& 233:14b. Copenhaver, Hermetica, Cambridge, 1992, p. 46.

20. Libellus I.19.7, Scott, Hermetica, p. 125: 'And when God had thus spoken, his Providence, by means of Destiny and the structure of the heavens [i.e. astral influences] brought about the union of male and female, and set the births going. Libellus XII (I) 6-7, Scott, Hermetica, p 227: 'Now all men are subject to destiny, inasmuch as all are subject to birth and death...It is impossible for a man to escape from his destined death' just as it is impossible for him to escape from his destined birth.'

21. Scott, Hermetica, p. 121 (Libellus I, para 12-13a) 'But Mind the Father of All, he who is Life and Light, gave birth to Man, a being like to Himself....And Man took station in the Maker's sphere [the highest sphere of heaven, the abode of Mind the Maker].'

22. Nature in the text is physis. She is the source of bodies.

23. I have relied upon the following alchemical texts as the backdrop for this section: A Testament of Alchemy being the Revelations of Morienus, ancient adept and hermit of Jerusalem to Khalid ibn Yazid, ibn Mu `awiyya, king of the Arabs of the divine secrets of the magisterium and accomplishment of the alchemical art, edited and translated from the oldest manuscripts by Lee Stavenhagen, published for Brandeis University Press by the University Press of New England, Hanover,

Culture and Cosmos 
New Hampshire, 1974; The Conjurer's Magazine or, Magical and Physiognomical Magazine (also known as the Astrologer's Magazine), Oct. 1792. Especially page 89: 'The Universal Wisdom of Peter John Faber, the most acute physician and philosopher'; A Lexicon of Alchemy or Alchemical Dictionary (1612), Martinus Rulandus, Kessinger, 1991.

\section{The Conjurer's Magazine, Oct. 1792. page 89ff:.}

25. I rely especially on Ancient Astrology Theory and Practice: The Mathesis of Firmicus Maternus. trs. Jean Rhys Bram, Noyes Press, Park Ridge, NJ. 1975, written in the late 4th century CE. Firmicus cites Hermes as one of his sources and generally seems to be perpetuating a kind of astrology quite similar to that found in the Liber Hermetis Trismegisti in Abhandlungen der Bayerischen Akademie der Wissenschaften, (Neue Folge) 12, 1936. 'Neue astrologisches texte des Hermes Trismegistos' von Wilhelm Gundel as also that found in Vettius Valens.

26. Firmicus, Mathesis, Bk. 4, praefatio, 5, p 156, 'And you, courses of the everlasting stars, and also Moon, mother of human bodies; and you chief of the stars, who from the monthly courses of the Moon, takes away her light and likewise returns it, Sun, best and greatest, who day after day order all things above all things with the rule of thy majesty, through whom, by divine decree, immortal soul is imparted to all living things...' ; Cf. also p.17, p.21.

27. Firmicus, Mathesis, Bk. 7.1:2, p 233, 'who set up the stars as stations for the ascent and descent of the souls....'

28 Also Firmicus, Mathesis, Bk. 1, proemium, 5, p. 12, 'You mentioned the twelve signs of the Zodiac and the effects of the five eternally wandering planets; the daily and the annual path of the Sun; the swift motion of the Moon and its waning and waxing; the number of revolutions it takes to make the greater year, which is often spoken about, in which the five planets and the Sun and the Moon are brought back to their original places; it is completed, you said, in the 1461st year. Cf. also Bk. 3, 1.9 , p.74, 'We have said, and there is universal agreement, that the apokatastasis takes place through fire and flood.'

29. Firmicus, Mathesis, Bk. 7, 1.2, p. 233.

30. Firmicus, Mathesis, Bk. 1, 2.4, p. 32.

31. Firmicus, Mathesis, Bk. 1, 1.1, p.32. 
34 The Hermetica as Ancient Science

32. I have used Thomas Taylor's translation, published by Stuart \& Watkins, London, 1961.

33. Plato, Timaeus 41

34. Scott, Libellus XIII, 2.

35. Dignificatio means 'to be made worthy' and is used in Cornelius Agrippa's De Occulta Philosophia, Liber III, chapter iii to describe the spiritual transformation necessary to change a profane man into a magician.

36. The equation of Heimarmene and Ananke with letters and numbers is my own conclusion based on the recognition that Destiny is linked with measure which in turn is inextricably connected with number, and that the Greeks had systems for equating numbers and letters. Again Heimarmene is intimately connected with Harmonia Mundi, a connection which is also unthinkable without number and letter.

Culture and Cosmos 